В. М. Чисніков, доктор юридичних наук, дочент Державний науково-дослідний інститут МВС України

V. M. Chysnikov, DSC (Law), Associate Professor

State Research Institute, MIA of Ukraine

\title{
Г. М. РУДИЙ - ВИДАТНИЙ УКРАЇНСЬКИЙ КРИМІНАЛІСТ-ПРАКТИК ПОЧАТКУ ХХ СТОЛІТТЯ (ДО 155-РІЧЧЯ ВІД ДНЯ НАРОДЖЕННЯ ТА 100-РІЧЧЯ ВІД ДНЯ ЗАГИБЕЛІ)*
}

H. M. RUDYI - FAMOUS UKRAINIAN FORENSIC PRACTITIONER OF THE BEGINNING OF THE 20TH CENTURY (TO THE 155TH BIRTHDAY ANNIVERSARY AND THE 100TH ANNIVERSARY OF THE DEATH)

Висвітлено життєвий шлях і новаторську службову діяльність начальника сискного відділення Київської міської поліції титулярного радника Георгія Михайловича Рудого (1863-1918 рр.) - талановитого сищика, одного з піонерів застосування науково-технічних засобів у боротьбі зі злочинністю в Російській імперії, у тому числі валізи сищика (слідчого чемодана), батька вітчизняної дактилоскопії та службового собаківництва, родоначальника поліцейської експертно-криміналістичної служби на території України, а також автора першого в Росії документа (інструкції) з регулювання діяльності чинів сискної поліції.

Ключові слова: Г. М. Рудий; дактилоскопія; слідчий чемодан; собаки-шукачі; Інструкція чинам Київської сискної поліції; історія криміналістики.

Освещены жизненный путь и новаторская служебная деятельность начальника сыскного отделения Киевской городской полиции титулярного советника Георгия Михайловича Рудого (1863-1918 гг.) - талантливого сыщика, одного из пионеров применения научно-технических средств в борьбе с преступностью в Российской империи, в том числе чемодана сыщика (следственного чемодана), отца отечественной дактилоскопии и служебного собаководства, родоначальника полицейской экспертно-криминалистической службы на территории Украины, а также автора первого в России документа (инструкции) по регулированию деятельности чинов сыскной полиции.

Ключевые слова: Г. М. Рудой; дактилоскопия; следственный чемодан; собакиищейки; Инструкция чинам Киевской сыскной полиции; история криминалистики.

The article describes the path of life and innovative official activities of the head of criminal investigation department of Kyiv City Police of the titular counsellor Heorhii Mykhailovych Rudyi (1863-1918). The author describes H. M. Rudyi as a talented criminal investigator, one of the pioneers of the use of scientific and technical means in the fight against crime in the

\footnotetext{
* Продовження. Початок статті див.: Криміналіст. вісн. 2018. № 1 (29). С. 175-188.
}

๑ В. М. Чисніков, 2018 
Russian Empire, the father of domestic fingerprinting and service dog breeding, investigator's kit, ancestor of the police forensic service in Ukraine, as well as the author of the first in Russia document (instruction) on regulating the activities of criminal investigation department officers.

Key words: H. M. Rudyi; dactyloscopy; investigator's kit; tracking dogs; Instruction to the officers of Kyiv criminal investigation police; history of criminalistics.

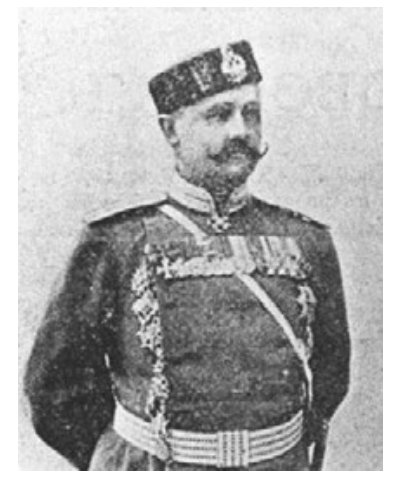

Цихоцький B. I.

У серпні 1903 р. Київський поліцмейстер полковник В. І. Цихоцький, повернувшись до Києва з Німеччини, де він відвідав Дрезденську виставку благоустрою міст і міську кримінальну поліцію, відрядив начальника сискної поліції Г. М. Рудого на означену виставку для ознайомлення з найновішими вдосконаленнями у сфері кримінальної поліції з метою застосування їх у київському сискному відділенні [5, с. 4-5]. Закордонне відрядження тривало два тижні. У Дрездені Г. М. Рудого насамперед зацікавив новий метод кримінальної реєстрації: ототожнення злочинців за допомогою дактилоскопії (відбитків десяти пальців рук). Упродовж останніх років цей метод успішно почала використовувати кримінальна поліція Англії, Німеччини, Австро-Угорщини та ін. 3 Дрездена Г. М. Рудий вирушив до Берліна, а потім до Відня, де ознайомився з організацією розшукової справи в цих містах та принципами дактилоскопії.

Повернувшись 3 відрядження, переконаний прибічник нового методу ідентифікації Г. М. Рудий уперше в Росії організував при антропологічному кабінеті дактилоскопічне бюро, яке почало діяти 31 січня 1904 р., а також розробив проєкт організації дактилоскопічних бюро в масштабах Російської імперії і 13 жовтня 1903 р. представив його начальству [Там само, с. 5]. Документ із 20 сторінок містив 4 розділи: 1. Антропометрична система. 2. Новий дактилоскопічний метод. 3. Організація дактилоскопічних бюро.

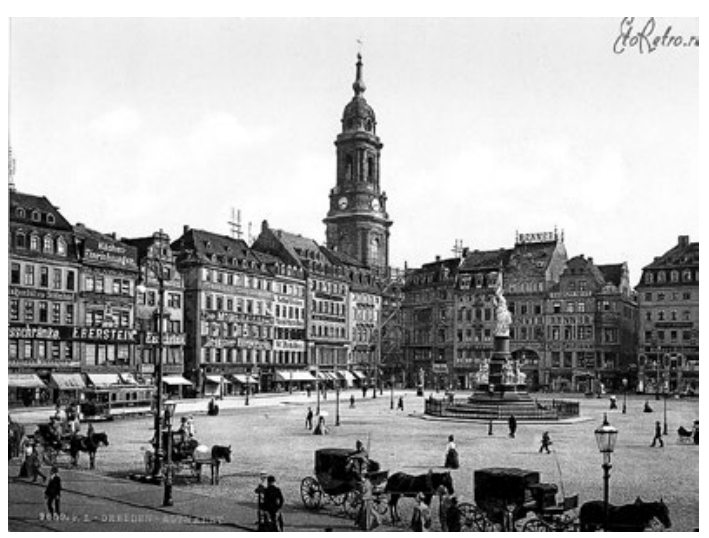

Дрезден, початок XX ст.

4. Розшук злочинця за дактилоскопічними відбитками.

Віддаючи перевагу дактилоскопії перед антропометрією, керманич київської сискної поліції писав, що неймовірна дешевизна дактилоскопічних приладів (лупа, пластинка, валик та фарба) і надзвичайна простота маніпуляцій, що не потребують ніяких приготувань, дають повну можливість без особливих витрат організувати дактилоскопічні виміри не тільки у в'язницях, а й у станових квартирах поліцейських наглядачів заштатних міст, посадів, містечок і сіл [Там само, с. 15]. Для цього Георгій Михайлович пропонував організувати чітку систему дактилоскопічних бюро:

1) повітові і приватні - при повітових і губернських в'язницях, виправних відділеннях та інших місцях ув'язнення, а в селищах, де немає місць ув'язнення, - при місцевому поліцейському управлінні або у старшого поліцейського чиновника; 
2) губернські - при губернській в'язничній інспекції або сискному відділенні (якщо воно є);

3) центральне - при Головному в'язничному управлінні або при Санкт-Петербурзькій сискній поліції.

У кожному бюро повинні були бути:

лупа;

цинкова пластина розміром «в кредитный рубль»;

валик;

флакон друкарської фарби;

бланки карток за формами № 1 i 2 ;

особлива шафа з відповідною кількістю шухляд для розподілу дактилоскопічних карток форми № 1 в порядку класифікації і карток № 2 суворо за абеткою.

Для розшуку злочинців Г. М. Рудий пропонував складати розшукові листки на червоному папері (форма № 6) і замість прикмет зазначати номер дактилоскопічної класифікації (формулу). Ці листки необхідно було розсилати до Центрального і всіх губернських дактилоскопічних бюро. За таких умов, говорив він, успіх розшуку цілком буде забезпечений [Там само, с. 20].

Проте в Департаменті поліції на той час дотримувались інших поглядів і віддавали перевагу антропометрії. Попри те, що проект Г. М. Рудого не підтримали в Петербурзі, він не зневірився в можливостях дактилоскопії. У 1904 р. Георгій Михайлович склав для чинів антропологічного кабінету посібник для дактилоскопічного дослідження доктора Віндта, основні положення якого увійшли до розробленої ним Інструкції чинам Київської сискної поліції. У січні 1905 р., після схвалення прокурором окружного суду, її згідно з розпорядженням Київського губернатора видано окремою брошурою.

Інструкція Г. М. Рудого обсягом сто п'ятдесят сторінок мала

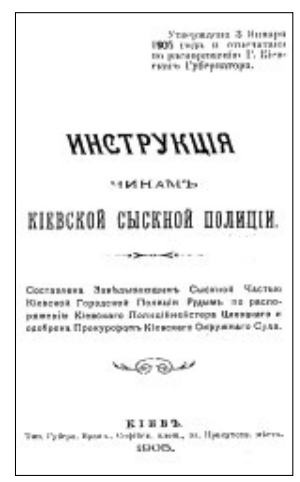
«кишеньковий» розмір, що зумовлювалося необхідністю завжди носити ії при собі чинам сискної поліції. Складалася вона з десяти глав і містила 205 параграфів. Питанням дактилоскопії присвячувалося майже 30 параграфів.

Уперше про відбитки пальців рук згадується у § 58 III відділення «Виявлення злочинів» VII глави «Особливий наказ чинам сискної поліції», де, приміром, ішлося про те, що коли при огляді місця злочину на розбитому склі збереглися сліди пальців, то осколки ці потрібно старанно зберегти.

Слідам рук і пальців у відділенні «Збереження і зняття слідів злочину» (§ 75-76) присвячено спеціальний підпункт. Зокрема в ньому зазначається, що сліди рук, а особливо пальців, де б вони не були знайдені, повинні бути обов'язково збережені в повній недоторканності. При цьому предмети, які легко переносяться і на яких є сліди пальців, доставляються до антропологічного кабінету сискного відділення для дактилоскопічного дослідження, а предмети, які неможливо доставити, - прикриваються і опечатуються (§ 75).

Для точного визначення, чи дійсно виявлені відбитки пальців залишені сторонніми особами, а не самим убитим або кимось із його домашніх, рекомендувалося з дозволу слідчих зняти відбитки пальців покійного і всіх членів його сім'ї. Дактилоскопіювання здійснювали за допомогою спеціальної пластинки, а в разі її відсут- 
ності - на злегка закопченому склі. Дозволялося використовувати і чисте скло, але при цьому потрібно було попередньо змазати пальці жиром (§ 76).

Основні питання з дактилоскопії розглянуто у главі «Особливі обов'язки чинів сискної поліції, які несуть внутрішню службу», зокрема у відділеннях «Антропологічний кабінет» (§ 158-161, 165, 167174) та «Поліцейська фотографія» (§ 176, 184194). Серйозні вимоги ставилися до посадових осіб антропологічного кабінету. Зокрема, вони повинні бути грунтовно знайомі з антропометрією, дактилоскопією і фотографією, а також медичними назвами окремих частин людського тіла. Згідно з Інструкцією особи, одержимі слабким зором, який заважає розглядати дактилоскопічні відбитки, або тремтінням рук, яке перешкоджає правильно володіти вимірювальними інструментами,

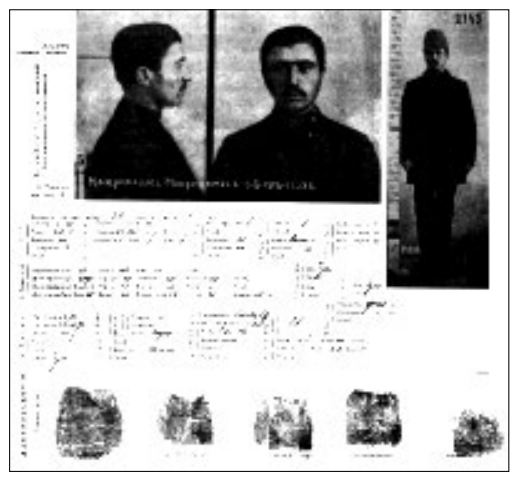

Реєстраційна дактилоскопічна картка на службу в антропологічний кабінет зовсім не приймаються (§ 158-159).

Серед обов'язкових предметів, які повинні бути в антропологічному кабінеті, значилися (§ 160):

керівництво для дактилоскопічного дослідження доктора Віндта;

валик і 2 пластинки для дактилоскопічних відбитків;

умивальник;

рушник і дезінфекційне мило для обтирання рук;

бензин або скипидар для відмивання рук від фарби;

значна кількість запасних дактилоскопічних бланків;

алфавіт (журнал) для запису осіб, яких дактилоскопіювали, та необхідна кількість шаф для розміщення дактилоскопічних карток.

Як зазначалося в Інструкції, дактилоскопічні картки мали заповнювати в 2-х примірниках. Перший примірник поміщали до належного ящика шафи № 4, в якому картки розподіляли в порядку їх класифікації за відбитками пальців, а другий - до відповідного ящика шафи № 5, в якому картки розподіляли за алфавітом (§ 161).

Дактилоскопічне обстеження затриманих осіб здійснювали після проведення антропологічних вимірів. Відбитки пальців обох рук ставили на особові картки за визначеною формою і заповнювали всі необхідні відомості. На бажання затриманого йому видавали бензин або скипидар для відмивання кінчиків пальців рук від мастики (§ 165).

Після закінчення дактилоскопічного обстеження дактилоскопічні картки затриманого поміщали до відповідних підрозділів шаф № 3 і 4. При цьому, звіряючи дані, з'ясовували, чи не була затримана особа раніше зареєстрована під іншим прізвищем. Якщо так, складали окремий протокол, до якого додавали копії всіх карток на затриману особу і вживали необхідних заходів для її встановлення.

Усі оригінали карток зберігали в ящику відповідного підрозділу (§ 167). Осіб, які пройшли дактилоскопіювання, реєстрували в спеціальному журналі (алфавіті), що зберігався в антропологічному кабінеті (§ 168).

Під час антропологічного дослідження на вимірювальну картку заносили відбитки лише 4-х пальців затриманої особи, що передбачали правила бертільйонажу 
(§ 164). У разі знайдення трупа невідомої людини завідувач антропологічного кабінету зобов'язаний був провести його антропологічне та дактилоскопічне дослідження, а фотограф - фотографування.

Інструкція докладно регламентувала дії завідувача антропологічного кабінету в разі виявлення на місці злочину слідів пальців рук. Зокрема, він з дозволу завідувача сискної частини разом із фотографом повинен був відправитися на місце події і за вказівкою судового слідчого провести необхідне дослідження та фотографування слідів. Виявлені сліди пальців рук необхідно було зберегти на кожному предметі, зважаючи на матеріал предмета. Для цього рекомендувалося навколо сліду прибити або приклеїти дерев'яну рамку (чи картон), зверху рамки покласти картон так, щоб він не торкався сліду (за потреби картон можна прибити). Під час дослідження відбитків пальців потрібно звернути увагу на те, пальці якої руки (лівої чи правої) i які саме відбилися. Це з'ясовували за місцем знаходження та розміщення відбитків (§ 173). В Інструкції також було визначено порядок класифікації відбитків пальців рук і виведення дактилоформул (§ 174).

Y VII відділенні «Поліцейська фотографія» VIII глави десять параграфів із двадцяти присвячувалися дактилоскопії. Зазначалося, що поліцейська фотографія слугує допоміжним закладом для антропометричного кабінету. Для того щоб поліцейська фотографія функціонувала без перебоїв, у ній завжди мають бути такі предмети:

фотографічний апарат з усім до нього приладдям;

повний фотографічний матеріал;

шафи для зберігання негативів і фотографічних матеріалів;

порошки графіту, індиго, алюмінію, фосфорного антимонію, крейди, каоліну, синьки, судану і пилу морської трави для посипання дактилоскопічних відбитків на місці злочину (§ 156-176).

Інструкція містила обов'язки поліцейського фотографа щодо фотозйомки, виготовлення фотокарток, зберігання негативів, надавався там і перелік способів фотографування відбитків пальців на різних поверхнях (наприклад, сліди пальців, відбиті на різнокольоровому папері, рекомендувалося знімати під навскісними променями світла; § 177-194).

Також докладно регламентувався порядок фотографування відбитків пальців, залишених на різних предметах. Перед фотозйомкою потрібно було посипати відбитки пальців одним із зазначених порошків (залежно від кольору предмета). Після цього предмет перевертали донизу, щоб осипався зайвий порошок. Якщо відбиток знаходився на неповоротному або нерухомому предметі, то зайвий порошок слід було здувати гумовою кулястою пляшкою (§ 184). Під час виготовлення фотографічних знімків відбитки пальців збільшували в два-три рази (§ 185).

У наступних параграфах надавалися конкретні рекомендації зі знімання відбитків і їх фотографування залежно від текстури та кольору предмета, на якому їх виявили: на білому, прозорому, темному предметах, склі, фарфорі із синім забарвленням, полірованих блискучих металевих предметах, блискучій шкірі, полірованому дереві, темно пофарбованих залізних касах, пилу, фарбі, воску, сургучі, тісті, різнокольоровому папері тощо. Так, наприклад, сліди, які відбилися на блискучій шкірі, полірованому дереві і темно пофарбованій залізній касі, потрібно було посипати білим порошком (каоліном) і фотографувати під навскісними променями світла (§ 191). 
Слід наголосити, що Інструкція чинам Київської сискної поліції була першим в Росії нормативно-правовим актом, який юридично закріпив використання в поліцейській практиці дактилоскопії як одного із методів кримінальної реєстрації та визначив різні способи її практичного використання в боротьбі зі злочинністю.

В Інструкції велику увагу було приділено й призначенню сискного відділення, його особовому складу, умовам прийняття на службу до сискної поліції, розподілу занять і порядку дій чинів сискного відділення, їхнім правам і обов'язкам (ці питання викладено в перших шести главах).

Так, згідно з Інструкцією сискне відділення мало спеціальне призначення, що полягало у виявленні злочинів, запобіганні їм і їх припиненні, розшуку злочинців і всього добутого злочинним шляхом, реєстрації всіх злочинців і підозрюваних осіб, ототожненні злочинців за допомогою антропологічного дослідження, а також реєстрації візників, швейцарів, двірників і сторожів (§ 1).

До кандидата на службу до сискної поліції висували певні вимоги: наявність таких якостей, як спритність, спостережливість, холоднокровність, рішучість, міцна статура, гарний слух, гострий зір, тверезість і чесна поведінка, вміння читати і тямуче писати по-російськи, а також добре знання міста Києва, його передмість та місцевих умов (§ 6). Заборонялося приймати на службу осіб, які мали торговельні або промислові заклади і в яких дружини, діти, брати і сестри займалися злочинним промислом (§ 8).

Сискні чини зобов'язані були завжди діяти цілком таємно і надто обачливо, все знати, все бачити і водночас намагатися не бути ніким поміченими. Вони мали зберігати ввірену їм службову таємницю і нікому зі сторонніх не розповідати про цілі та плани своїх службових дій, у розмовах з ким-небудь бути надто стриманими і тактовними (§ 35), виконуючи службові обов'язки, виявляти холоднокровність, терплячість і ввічливість, у жодному разі не дозволяти собі ображати причетних до справи осіб словами або діями (§ 36).

Цікавою є вимога Інструкції стосовно речей, які завжди повинен був мати при собі кожний чин сискної поліції. Це (§ 41):

власне ця Інструкція;

записник з хімічним олівцем;

книжка з відривними купонами для запису повідомлень про події;

сигнальний свисток з гудком;

кишенькова рулетка;

лупа;

шматок воску, крейда;

ручний ланцюжок особливого зразка для застосування до особливо небезпечних злочинців, які чинили опір під час затримання або намагалися втекти.

Найбільшою та найважливішою частиною Інструкції була VII глава «Особливий наказ чинам сискної поліції», яка поділялася на дев'ять відділень: I «Положення загальне»; II «Про запобігання злочинам»; III «Виявлення злочинів»; IV «Розшукування слідів злочинця»; V «Зберігання і зняття слідів злочину»; VI «Дізнання»; VII «Висліджування злочинців»; VIII «Розшуки, обшуки і виїмки»; IX «Особисте затримання».

Певний інтерес становлять IV i V відділення. Так, у IV відділенні (§ 70) ішлося про використання собак для розшуку злочинців, де наголошувалося, що в багатьох випадках при відшуканні слідів злочинців, неясно відбитих або загублених на проїзній 
дорозі, можуть надати незамінну послугу собаки-шукачі. у § 106 зазначалося, що, розшукуючи труп, закопаний у землю, дуже добре облити землю гарячою водою і потім пустити собаку-шукача для обнюхування ґрунту після деякого випаровування.

Важливе значення для практичного втілення наукових методів боротьби зі злочинністю має V відділення, де регламентовано такі прийоми для зберігання та зняття слідів злочину, наукою і практикою вироблені:

складання шматків розірваного і спаленого паперу;

зберігання і зняття слідів крові;

зберігання і зняття відбитків рук і пальців;

зберігання і зняття слідів ніг, копит і возів;

зберігання і зняття інших слідів.

В Інструкції, зокрема, зазначалося, що залишені на місці злочину предмети, особливо одяг, нерідко можуть стати в нагоді для встановлення особи або професії злочинця. Тому ці предмети повинні бути старанно збережені. Наводився приклад, коли на місці злочину знайшли піджак, а після вибивання його над білим папером з нього посипалися мідні ошурки. Пізніше з'ясували, що злочинець працював гравером (§ 88).

Регламентуючи діяльність чинів сискної поліції із запобігання злочинам, їх виявлення та розкриття, Інструкція не містила рекомендацій щодо застосування таємної агентури, хоча про використання агентурних даних ішлося в деяких параграфах цього документа. Зокрема, у § 89 рекомендувалося пропускати через фільтр дізнання усякі одержувані агентурні у справі відомості, якими б вони дивними не здавалися, і ті з них, які виявляться достовірними, класти в основу дізнання.

VIII главу Інструкції присвячено особливим обов'язкам чинів сискної поліції, які несли внутрішню службу. Вона містила вісім відділень: І «Обов'язки чергового чиновника і агента»; II «Обов'язки заступника завідувача сискної частини»; III «Стіл подій»; IV «Стіл особового затримання»; V «Стіл довідок і нагляду»; VI «Антропологічний кабінет»; VII «Поліцейська фотографія»; VIII «Канцелярія сискного відділення».

Так, у VI відділенні надавався перелік необхідних предметів, які повинні бути в антропологічному кабінеті, порядок антропометричних вимірювань і зняття дактилоскопічних відбитків пальців (у тому числі й трупів), а також заповнення антропометричних і дактилоскопічних листків. Значне місце відводилось обов'язкам завідувача кабінету і фотографа щодо досконального дослідження та фотографування слідів пальців рук, знайдених на місці злочину, способів їх зберігання, порядку виведення дактилоформули тощо (§ 156-174).

Важливе значення для професійного навчання чинів сискної поліції мала IX глава «Розподілення злочинців за спеціальностями і способами скоєння злочинів», де наводилася характеристика 27 видів злочинних спеціальностей.

У заключній, X главі «Порядок сигналізації» викладено дев'ять сигналів, які подавали за допомогою спеціального гудка чини сискної поліції, спілкуючись між собою (§ 205).

Таким чином, розроблена Г. М. Рудим Інструкція чинам Київської сискної поліції була першим в Росії нормативно-правовим актом, який не лише юридично закріплював використання в поліцейській практиці дактилоскопії як одного з методів кримінальної реєстрації та визначав різні способи її практичного використання в боротьбі зі злочинністю, а й регламентував усебічні аспекти організації та діяльності сискного відділення, був універсальним практичним посібником криміналіста 
(на той час у системі МВС Російської імперії подібного нормативного акта не існувало; лише через п'ять років Департамент поліції видав Інструкцію чинам сискних відділень (1910р.), але вона за своїм обсягом і змістом поступалася Київській). Також у цьому документі вперше в Російській імперії закріплювалося використання в поліцейській практиці службово-розшукових собак [11].

Слід нагадати, що Міністерству внутрішніх справ загалом знадобилося понад три роки після отримання проекту Г. М. Рудого, щоб сформувати при Департаменті поліції Центральне реєстраційне бюро, а в сискних відділеннях на місцях - реєстраційні бюро, в яких використовували дактилоскопію, хоча їх низову повітову ланку, на якій наполягав Георгій Михайлович, так і не було створено. Попри структурні зміни, що мали сприяти розвитку дактилоскопії в Росії, вона стала головним методом кримінальної реєстрації лише наприкінці 1914 р. Антропометричний метод і далі використовувався для ототожнення «старих» рецидивістів. Таким комбінованим методом ідентифікації злочинців, на відміну від європейських держав, у Росії послуговувалися до 1917 р., а в Україні - до середини 1920-х рр.

Нереалізованою залишилась і пропозиція Г. М. Рудого щодо створення єдиного реєстраційного центру, до якого б надходили дактилоскопічні картки як від пенітенціарних, так і від поліцейських установ. Створені в 1907 р. Центральні дактилоскопічні бюро при Головному тюремному управлінні Міністерства юстиції і Департаменті поліції МВС дбали про вузьковідомчі інтереси, користувалися різними системами реєстрації, відомості не узагальнювали та не доводили один одному. У результаті, як зазначав один із відомих дореволюційних криміналістів С. М. Трегубов, страждала загальнодержавна справа [12, с. 254].

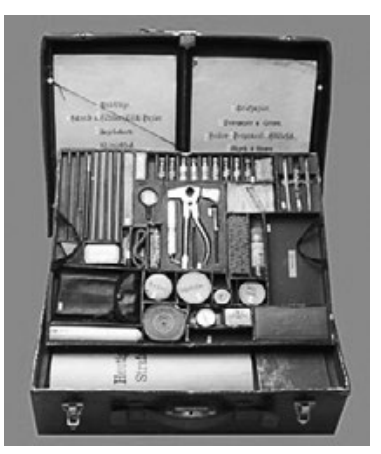

Дактилоскопія була не єдиною новацією Г. М. Рудого у вітчизняній сискній справі, запозиченій на Заході. Перебуваючи у вересні 1903 р. на Дрезденській виставці, Георгій Михайлович звернув увагу на один цікавий експонат серед новинок поліцейської техніки. Це була невелика за розмірами валіза, оснащена великою кількістю інструментів і приладів, необхідних для виявлення і дослідження речових доказів, знайдених на місці події. Це, так би мовити, був прабатько сучасної валізи слідчого, винахідником якої вважається відомий австрійський учений-криміналіст Ганс Гросс. Ще на початку 90-х рр. XIX ст. він рекомендував слідчим послуговуватися «дорожньою сумкою», використовуючи для цього різні типи офіцерських сумок з різними речами для складання протоколів, планів $i$ оглядів. На думку вченого, у цій сумці повинно було бути двадцять чотири предмети, призначення яких він детально описував. Пізніше Ганс Гросс доповнив зазначений перелік новими предметами. Зокрема, він рекомендував мати моток хороших тонких мотузок (шестерик), необхідних для вимірів, пакування речових доказів, лагодження поламаних предметів тощо. Для роботи з отруйними предметами серветки з сулемою, а для слідчих із короткозорістю - бінокль або підзорну трубу. В одній із праць учений-криміналіст зазначав, що він отримав стільки листів від своїх товаришів по службі з різних країн, що має право зробити висновок, що ця сумка для слідчих, безумовно, необхідна [13, с. 181]. І дійсно, невдовзі його ідею було матеріалізовано, і на виставці у Дрездені з'явився один із перших зразків слідчого чемодана. 
Уважно ознайомившись із предметами, якими укомплектовано валізу слідчого, Г. М. Рудий переписав їх у свій записничок. Георгій Михайлович добре розумів, що валіза сищика постане надійним помічником чинам сискної поліції, які здебільшого першими прибувають на місце події і провадять дізнання. Г. М. Рудий більш докладно ознайомився із вмістом чемодана в поліцейських управліннях Берліна і Відня. Повернувшись із закордонного відрядження, Георгій Михайлович за власний кошт не лише зробив у Києві такий самий чемодан, а й удосконалив його, доповнивши багатьма приладами, необхідними для місцевих умов [5, с. 5]. Про це він не без гордості зазначав у своєму звіті.

Результати аналізу літературних і архівних матеріалів свідчать, що це фактично був перший в Росії слідчий чемодан, який почали використовувати чини сискної поліції для огляду місця події.

Досвід Г. М. Рудого щодо створення слідчого чемодана не забутий і його послідовниками. У звіті про діяльність Київського кабінету науково-судової експертизи за 1914 р. зазначалося, що під час виїздів на місце події чини кабінету користуються дактилоскопічними приладами у вигляді ящиків, уяких знаходяться пристрої для фіксації і отримання відбитків пальців [14, с. 323].

Реорганізація Київської сискної поліції, як зазначав сам Георгій Михайлович, завершилась у грудні 1904 р. придбанням для розшукових цілей у Швельмі (Німеччина) чотирьох собак-шукачів - вівчарок різної статі, зокрема премійованої на змаганнях поліцейських собак дворічної Гексе, яка кілька місяців прослужила в німецькій поліції і відзначилася під час затримання двох злочинців.

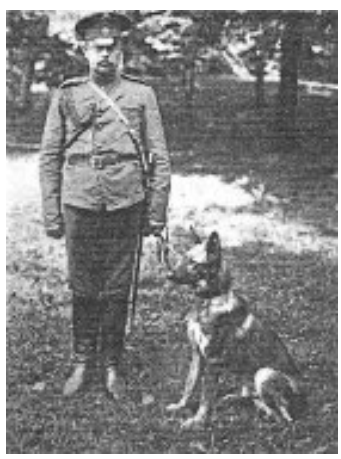

Стражник Покровський

зі сискним собакою «Кузя»

Після придбання за кордоном собак-шукачів при сискному відділенні запровадили посаду дресирувальника собак. Для історії збереглося навіть ім'я та прізвище першого київського дипломованого кінолога - Олександр Ергант. У листопаді 1904 р. за рекомендацією Г. М. Рудого його відрядили до Швельма для детального ознайомлення зі способом дресирування і виховання поліцейських собак. Упродовж місяця Ергант сумлінно вивчав премудрості службового собаківництва і повернувся до Києва, маючи засвідчений встановленим порядком атестат про успішне вивчення способу дресирування і виховання собак [5, с. 35].

Купівля собак-шукачів і навчання за кордоном кінолога обійшлися державній казні у 695 руб. 50 коп. Наступного року на доставку з-за кордону поліцейських псів і їх утримання було витрачено ще 745 руб. 21 коп. Щомісяця утримання однієї вівчарки разом із приміщенням обходилося сискному відділенню у майже 5 руб. Нащадки цих собак, тоді звітував Г. М. Рудий, дресируватимуться при сискному відділенні для розшуку по слідах і для захисту поліцейських чинів від нападів злочинців. І після іспиту їх поступово роздаватимуть чинам сискного відділення [Там само, с. 23].

Суттєву допомогу в дресируванні собак надавав німецький журнал «Поліцей-Гунд», один примірник якого передплачувало сискне відділення. Робилася спроба організувати і вітчизняний «Порадник». В Інструкції чинам Київської сискної поліції Г. М. Рудий зазначав, що про порядок користування послугами цих тварин $і$ 
виховання їх указуватиметься в особливому пораднику [10, с. 35]. На жаль, знайти в архівах цей нормативний акт поки що не вдалося.

Собак-шукачів успішно використовували в розкриттізлочинів, зокрема вбивств, що засвідчує протокол (копія) від 17 січня 1905 р., виявлений автором цієї статті (як і портрет Г. М. Рудого) у Державному архіві Російської Федерації (Москва):

«Копия

\section{Протокол}

1905 года января 17 дня. Состоящий при сыскной части Киевской городской полиции чиновник Унгурян, совместно с агентом-дрессировщиком полицейских собак Эргантом, согласно поручению заведующего сыскной частью Киевской городской полиции, сего числа отправились на Наводницкую улицу, где совершено убийство Евдокии Федоровны Ивасько, и при помощи полицейской собаки Гексе произвели розыск убийцы по следам. Собака Гексе, обнюхав место происшествия, а равно и труп убитой, начала обнюхивать собравшуюся там многочисленную толпу, но убийцы среди них не нашла. Тогда Гексе была доставлена в Печерский участок, где содержится под стражей заподозренный в убийстве муж Филипп Ивасько. Последний был выведен на площадь и поставлен среди собравшейся там толпы в числе 60 душ; собака снова стала обнюхивать всю толпу и когда подошла к Филиппу Ивасько, то набросилась на него и залаяла, потом сделала небольшой полукруг, опять набросилась на Ивасько и начала тормошить корзину, в которой лежала белая тряпка, и затем все время караулила Филиппа Ивасько.

ПОСТАНОВИЛ: об изложенном заключить настоящий протокол. Подлинный подписал: чиновник сыскной части Унгурян.

Верно:

Начальник Киевского сыскного отделения (подпись)» [15, л. д. 152].

Слід наголосити, донедавна в історико-правовій літературі зазначалося, що в Росії розшукові собаки вперше з'явилися на поліцейській службі в 1906 р. [16, с. 27]. Наведений вище документ переконливо свідчить про те, що російська кінологічна служба системи МВС бере свій початок із Києва, а одним з її засновників був Георгій Михайлович Рудий.

У серпні 1905 р. Георгій Михайлович підготував доповідь Київському генерал-губернатору про подальшу реорганізацію сискного відділення, зумовлену ускладненням оперативної обстановки, пов'язаної з революційними подіями в державі і наслідками російсько-японської війни. Зокрема, він порушував питання про збільшення чисельності сискної поліції, якісний підбір кадрів, створення курсів з підготовки спеціалістів карного розшуку, видання поліцейської газети, проведення з'їздів сискних чинів для обміну досвідом тощо.

Стосовно необхідності видання поліцейської газети Г. М. Рудий ще раніше писав, що майже всі відомства в імперії, не виключаючи телеграфне, вся діяльність якого полягає в рисочках і крапках, та волосних правлінь, що відають маловажливими селянськими справами, мають свої спеціальні газети, а численна поліція, діяльність якої так багатоскладна і різноманітна, свого друкованого органу не має. 3 метою повного об'єднання дій органів поліції та постійного між ними обміну думок необхідно відкрити спеціальну поліцейську газету, або ж доповнити «Губернські Відомості», що видаються нині, поліцейським відділом, в якому були б розміщені пе- 
редові статті з різних питань поліцейської діяльності та кримінальної антропології, статті з дослідження злочинності та злочинців, відомості про всі події в губернії, мемуари по виявленню більш загадкових злочинів як у нас, так і за кордоном. Ці мемуари знайомитимуть поліцейських чинів з розшуковими прийомами видатних поліцейських діячів і з різними прийомами злочинців [5, с. 149].

Коли Г. М. Рудий писав про труднощі в діяльності сискного відділення, то він наголошував, що обов'язки діловода та завідувачів відділів особистого затримання, подій і спостережень виконують городові сискної частини, люди нерозвинені і недосвідчені; тому доводиться контролювати кожен іх крок, коригувати їх письмові роботи. Через брак помічника він повинен постійно сидіти в кабінеті з 8:00 ранку до 12:00 ночі для прийому відвідувачів і для провадження дізнання особливої важливості, завдяки чому позбавлений фізичної можливості особисто керувати всіма діями агентів і змушений обмежуватись активною участю в більш важливих справах. Відсутність заступника не дає можливості скористатися дозволеною йому в цьому році єдиною за 13 років служби в поліції закордонною відпусткою для лікування мінеральними водами [17, арк. 2].

У січні 1907 р. Київську міську поліцію очолив новий поліцмейстер, підполковник М. О. Мартинов. Його попередника, полковника Цихоцького, під заступництвом якого перебував начальник сискної поліції Г. М. Рудий, переведено на нове місце служби (при цьому із «підмоченою» обвинуваченнями у зловживанні по службі репутацією). Хоча порушену проти Цихоцького кримінальну справу і припинено за відсутності підстав у приписуваному йому злочині, прокурор Київської судової палати наполягав на тому, щоб найближчі помічники поліцмейстера були притягнуті до відповідальності. Невдовзі київські газети почали обвинувачувати Г. М. Рудого у злов-

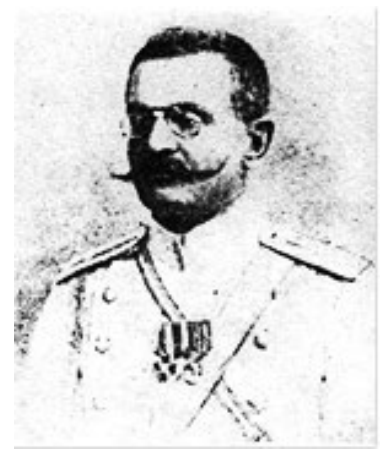

М. О. Мартинов живаннях владою і махінаціях при розкритті злочинів. У травні 1907 р. він був змушений залишити свою посаду та перейти на службу до Міністерства шляхів сполучення - завідувачем агентури з розшуку вантажів при Управлінні Південно-Західної залізниці.

Про «підстроювання» начальника київської сискної поліції пана Г. М. Рудого власника млина і ставу в с. Романівка згадує уродженець цього села класик української поезії Максим Рильський. У своєму творі «Мандрівка в молодість» (1944р.) він, зокрема, пише [18, с. 89]:

«...Начальник відділу сискного, пан Рудий

Тим ставом володів. Розказували люди, Щоб, службі помогти бажаючи своїй, Той пан підстроював (хоч варто це огуди) Крадіжки сам-таки - і розкривав як свій! Коли ж розкрилося оте нехитре чудо, Рудого звільнено... Але з яких причин Іще теплішого доскочив місця він?»

На новій посаді Георгій Михайлович працював до кінця 1917 р., дослужився до 
титулярного радника і розкрив сотні неочевидних злочинів (його десятилітня діяльність на залізниці ще чекає свого дослідника).

Працюючи і далі на ниві боротьби зі злочинністю, Г. М. Рудий деякий час викладав сискну справу на курсах урядників, відкритих у Києві в 1908 р., а також допомагав своїм колишнім колегам у розкритті резонансних кримінальних справ [19, с. 297].

Матеріали особової справи Георгія Михайловича Рудого свідчать, що на початку 1918 р. він проживав у Фастові Васильківського повіту Київської губернії, мав невеликий маєток, близько двох сотень десятин землі і водяний турбінний млин у с. Романівка Сквирського повіту Київської губернії.

20 січня 1918 р. Георгій Михайлович у листі до Голови Київської спілки земельних власників писав:

Розпочата купкою авантюристів аграрна реформа вилилася в найважчу і потворну форму анархії і загрожує повним руйнуванням всіх приватних землевласників і великим лихом для всієї країни.

Ці авантюристи з метою заманювання черні в свою сторону систематично видають різного роду постанови про передачу сільським хамам не тільки всієї землі, а й навіть живого і мертвого інвентарю і хліба з посівів. Сільські ж п'яниці, користуючись таким заступництвом узурпаторів влади, які, не відкидаючи санкції законної влади, взялися за здійснення цих незаконних постанов і зовсім розгромили всі приватновласницькі маєтки, перетворивши награбований хліб в горілку-самогонку, а награбовану іменну худобу продають на базарах на забій.

Усі скарги землевласників завжди залишаються гласом волаючого в пустелі, бо на чолі місцевих комітетів часто стоять кримінальні злочинці, а в комісари здебільшого потрапляють особи, які абсолютно не відповідають своєму призначенню.

Наприкінці листа Георгій Михайлович пропонував зібрати в найближчий час з'їзд землевласників і власників будинків, щоб обговорити питання щодо організації такої влади, яка була б спроможна захистити інтереси «усіх культурних верств населення» і, зокрема, землевласників, а також щодо асигнування на утримання такої влади потрібних коштів шляхом самообкладання тощо [4, арк. 118-119]. На жаль, цей документ останній у його особовій справі.

Донедавна подальша доля Г. М. Рудого залишалася невідомою. У попередніх публікаціях автора цієї статті зазначалося, що, цілком імовірно, пережити страшне лихоліття громадянської війни колишньому поліцейському сищику і піонеру вітчизняної криміналістики навряд чи вдалося [20, с. 141]. Це припущення виявилося небезпідставним. 3 посиланням на київську газету «Последние новости» за 1918 р. в Інтернеті було розміщено інформацію, в якій сповіщалося про те, як загинув Г. М. Рудий. У Центральному державному історичному архіві України знайшовся потрібний номер цього періодичного видання, де опубліковано таку статтю:

\section{«Убийство Г. М. Рудого.}

В утреннем номере «Посл[едние] Нов[ости]» сообщалось о нахождении в районе дворцового участка трупа неизвестного человека, который был доставлен в аптеку Горбачевского (Крещ[атик], 54) и никаких документов в карманах убитого не обнаружено было, почему личность убитого в течение двух дней не могло быть установлено. 
Третьего дня, благодаря случайному обстоятельству, удалось установить личность убитого: последний оказался б[ывшим] нач[альником] киевского сыскного отделения Г. М. Рудым.

Установление личности убитого произошло при следующих обстоятельствах: на указательном пальце убитого обнаружено было обручальное кольцо с надписью «Ксения. 1900 г. 8 октября». Один из знакомых убитого, прочтя в газетах о нахождении трупа и узнав по надписи на кольце имя жены убитого, поспешил к ней и сообщил ей о случившемся. Вместе с женой Рудого, оба отправились к месту нахождения трупа, где последний тотчас же был опознан.

Полагают, что Рудой был убит уголовными преступниками, хорошо знавшими его в лицо.

В последнее время покойный заведовал отделом розысков грузов на ю[го] з[ападных] дорогах, где проявлял неутомимую энергию по борьбе с уголовными преступниками» [21].

Так, на 55 році життя трагічно загинув один із найталановитіших українських розшуковців-криміналістів. Беручи до уваги матеріали газетної публікації, днем його загибелі слід вважати 25 (12) лютого 1918 р.

Майже століття ім'я Георгія Рудого перебувало в забутті. Сьогодні значущість його новацій у царині кримінального розшуку засвідчують кандидатські та докторські дисертації, монографії, підручники з криміналістики та сискології, енциклопедії, науково-популярні видання, телефільми, експозиції навчально-криміналістичних кабінетів закладів освіти, доповіді фахівців на міжнародних і вітчизняних науково-практичних конференціях тощо. У 2013 р. на 150-ліття з дня народження Георгія Михайловича у Хмельницькому університеті управління та права започатковано щорічні Всеукраїнські студентські змагання зі слідчих дій імені Г.М.Рудого. Їх мета - сприяти закріпленню студентами теоретичних знань та отримання навичок проведення слідчих дій. Отже, перефразовуючи одне з комуністичних гасел, можна впевнено сказати: «Справа Георгія Михайловича Рудого живе й перемагає» [22-33].

\section{References}

1. Chisnikov V. Kievskoe sysknoe otdelenie ne ustupalo «...po svoemu blagoustrojstvu ni odnomu iz pravilno organizovannyh v Rossii sysknyh policij» (Iz istorii ukrainskoj kriminalistiki) / V. Chisnikov. Kyiv, Volodymyrska, 15. 1997. № 14-15 (serp.).

2. Chysnikov V. M. Kryminalistyka v Ukraini v KhIKh - poch. KhKh st. / V. M. Chysnikov. Kryminalistyka: pidruch. dlia slukhachiv, adiunktiv, vykladachiv systemy MVS Ukrainy / za red. P. D. Bilenchuka. Kyiv, 1998. S. 43-58.

3. Chysnikov V. M. Kyiv - batkivshchyna rosiiskoi daktyloskopii ta odorolohii / V. M. Chysnikov. Imenem Zakonu. 1998. № 15. 10 kvit.

4. Lichnoe delo zaveduyushego sysknoj chastyu Kievskoj gorodskoj policii, titulyarnogo sovetnika Georgiya Mihajlovicha Rudogo (Dokumenty o prohozhdenii sluzhby, imushestve Rudogo. 3 iyulya 1884 g. - 20 yanvarya 1918 g.). Derzhavnyi arkhiv m. Kyieva (DAK). F. 237. Op. 3. Spr. 47.

5. Otchet o deyatelnosti sysknogo otdeleniya Kievskoj gorodskoj policii za 1902, 1903 i 1904 gg. Kiev, 1905. $150 \mathrm{~s}$.

6. Derzhavnyi arkhiv Kyivskoi oblasti (DAKO). F. 289. Op. 180. Spr. 152.

7. Tsentralnyi derzhavnyi istorychnyi arkhiv (TsDIAK). Kyiv. F. 442. Op. 632. Spr. 358.

8. Chysnikov V. M. Syskna politsiia v Ukraini za chasiv Rosiiskoi imperii (1880-1917 rr.): istoryko-pravove doslidzhennia: monohrafiia: u 2-kh kn. Kharkiv, 2014. Kn. II. 624 s.

9. Anufriev N. I. Tajny syska / N. I. Anufriev, A. M. Pidzharenko. Kiev, 2002. Kn. I. 524 s. 
10. Instrukciya chinam Kievskoj sysknoj policii. TsDIAK Ukrainy. F. 442. Op. 635. Spr. 668. Kyiv, 1905. $113 \mathrm{~s}$.

11. Chysnikov V. M. «Instruktsiia chynam Kyivskoi sysknoi politsii» (1905 r.) - vazhlyve dzherelo orhanizatsii ta diialnosti karnoho rozshuku Rosiiskoi imperii / V. M. Chysnikov. Derzhava i pravo. 2001. Vyp. 11. S. 59-62.

12. Tregubov N. S. Osnovy ugolovnoj tehniki: nauchno-tehnicheskie priemy rassledovaniya prestuplenij / N. S. Tregubov. M.: LeksEst, 2002. 336 s.

13. Gross G. Novye dannye iz oblasti kriminalistiki / G. Gross. Pravo. 1899. № 4. S. 179-184.

14. Kratkij ocherk deyatelnosti kabinetov nauchno-sudebnoj ekspertizy v 1914 godu. Zhurnal M-va yusticii. 1915. № 6. S. 323-345.

15. Gosudarstvennyj arhiv Rossijskoj Federacii. F. D-vo 8. Op. 1908. D. 14.

16. Krylov I. F. Rozysk, doznanie, sledstvie / I. F. Krylov, A. I. Bastrykin. L.: Izdatelstvo Leningrad. un-ta, 1984. $217 \mathrm{~s}$.

17. TsDIAK Ukrainy. F. 442. Op. 855. Spr. 530.

18. Rylskyi M. Zibrannia tvoriv: u 20 t. / Maksym Rylskyi. Kyiv: Nauk. dumka, 1983. T. 3. 439 s.

19. Reznik G. M. Delo Mendelya Bejlisa: materialy Chrezvychajnoj sledstvennoj komissii Vremennogo pravitelstva o sudebnom processe $1913 \mathrm{~g}$. po obvineniyu v ritualnom ubijstve / G. M. Reznik. SPb.: Dmitrij Bulanin, 1999. 393 s.

20. Chisnikov V. N. Rudoj Georgij Mihajlovich (1863 - posle 1917) / V. N. Chisnikov. Kryminalistychni reiestratsiino-dovidkovi y sudovo-ekspertni ustanovy Ministerstva vnutrishnikh sprav ta Ministerstva yustytsii Rosiiskoi imperii(1889-1917rr.): u2-kh kn. /Verbenskyi M. H., ProtsenkoT. O., Chysnikov V. M. ta in. Kyiv; Kharkiv, 2013. Kn. 1.

21. Poslednie novosti. 1918. 1 marta (16 fevr.).

22. Chysnikov V. M. H. M. Rudyi - maister politseiskoho rozshuku / V. M. Chysnikov. Imenem Zakonu. 2003. № 33, 34, 36, 37, 39-43.

23. Chysnikov V. M. Batko vitchyznianoi daktyloskopii / V. M. Chysnikov. Yuryd. visn. Ukrainy. 2003. 13-19 hrud.

24. Chysnikov V. M. H. M. Rudyi - pioner ukrainskoi kryminalistyky / V. M. Chysnikov. Yurydychna nauka ta osvita: istoriia, suchasnist, perspektyvy: materialy IKh istor.-prav. konf. (Rivne, 6-8 cherv. 2003 r.). Kyiv, 2004. S. 149-157.

25. Chysnikov V. M. H. M. Rudyi - pioner ukrainskoi kryminalistyky / V. M. Chysnikov. Kryminalist. visn. 2004. № 2. S. 134-1041.

26. Chisnikov V. N. G. M. Rudoj - novator policejskogo syska / V. N. Chisnikov. Operativnik (syshik). 2006. № 1 (6). S. 3-5; № 4 (9). S. 7-12.

27. Chysnikov V. M. Novatsii H. M. Rudoho v karno-rozshukovii spravi / V. M. Chysnikov. Nauka i pravookhorona. 2008. № 1. S. 132-138.

28. Chysnikov V. M. Kryminalistyka Ukrainy v KhIKh - poch. KhKh stolittia / V. M. Chysnikov. Kryminalistyka: pidruchnyk / za zah. red. P. D. Bilenchuka. Kyiv: Atika, 1998. S. 43-58.

29. Chysnikov V. M. Rudyi Heorhii Mykhailovych / V. M. Chysnikov. Mizhnarodna politseiska entsyklopediia: u 10 t. / vidp. red. Ye. M. Moiseiev, V. Ya. Tatsii, Yu. S. Shemshuchenko. Kyiv, 2009. T. V. Kryminalno-protsesualna ta kryminalistychna diialnist politseiskykh orhanizatsii. S. 74.

30. Chysnikov V. M. Rudyi Heorhii Mykhailovych / V. M. Chysnikov. Mizhnarodna politseiska entsyklopediia: u 8-my t. / vidp. red. Kovalenko V. V., Moiseiev Ye. M., Tatsii V. Ya., Shemshuchenko Yu. S. Kyiv, 2010. T. VI. Operatyvno-rozshukova diialnist politsii (militsii). S. 899.

31. Chisnikov V. N. Tri portreta masterov syska / V. N. Chisnikov. Antologiya syska: ot policii kvneshnej razvedke / otv. red. Rimarenko Yu. I., Chisnikov V. N., Kusherec V. I. Kiev, 2006. T. 2. S. 249-286.

32. Chysnikov V. M. Syskna politsiia v Ukraini za chasiv Rosiiskoi imperii (1880-1917 rr.): istor.-prav. doslidzh.: u 2-kh kn. / V. M. Chysnikov. Kyiv, 2011. Kn. I. Dokumenty i materialy. S. 307-353.

33. Chysnikov V. M. Metr sysknoi spravy. Kryminalistychni priorytety kyivskoho syshchyka Heorhiia Rudoho / V. M. Chysnikov. Yuryd. visn. Ukrainy. 2018. 4-17 trav. 


\section{Список використаних джерел}

1. Чисников $B$. Киевское сыскное отделение не уступало «...по своему благоустройству ни одному из правильно организованных в России сыскных полиций» (Из истории украинской криминалистики) / В. Чисников. Київ, Володимирська, 15. 1997. № 14-15 (серп.).

2. Чисніков В. М. Криміналістика в Україні в XIX - поч. XX ст. / В. М. Чисніков. Криміналістика: підруч. для слухачів, ад'юнктів, викладачів системи МВС України / за ред. П. Д. Біленчука. Київ, 1998. С. 43-58.

3. Чисніков В. М. Київ - батьківщина російської дактилоскопії та одорології / В. М. Чисніков. Іменем Закону. 1998. № 15. 10 квіт.

4. Личное дело заведующего сыскной частью Киевской городской полиции, титулярного советника Георгия Михайловича Рудого (Документы о прохождении службы, имуществе Рудого. - 3 июля 1884 г. - 20 января 1918 г.). Державний архів м. Києва (ДАК). Ф. 237. Оп. 3. Спр. 47.

5. Отчет о деятельности сыскного отделения Киевской городской полиции за 1902 , 1903 и 1904 гг. Киев, 1905. 150 с.

6. Державний архів Київської області (ДАКО). Ф. 289. Оп. 180. Спр. 152.

7. Центральний державний історичний архів (ЦДІАК). Київ. Ф. 442. Оп. 632. Спр. 358.

8. Чисніков В. М. Сискна поліція в Україні за часів Російської імперії (1880-1917рр.): історико-правове дослідження: монографія: у 2-х кн. Харків, 2014. Кн. II. 624 с.

9. Ануфриев Н. И. Тайны сыска / Н. И. Ануфриев, А. М. Пиджаренко. Киев, 2002. Кн. І. 524 с.

10. Инструкция чинам Киевской сыскной полиции. ЦДІАК України. Ф. 442. Оп. 635. Спр. 668. Київ, 1905. 113 с.

11. Чисніков В. М. «нструкція чинам Київської сискної поліції» (1905 р.) - важливе джерело організації та діяльності карного розшуку Російської імперії / В. М. Чисніков. Держава $i$ право. 2001. Вип. 11. С. 59-62.

12. Трегубов Н. С. Основы уголовной техники: научно-технические приемы расследования преступлений / Н. С. Трегубов. М.: ЛексЭст, 2002. 336 с.

13. Гросс Г. Новые данные из области криминалистики / Г. Гросс. Право. 1899. № 4. C. $179-184$.

14. Краткий очерк деятельности кабинетов научно-судебной экспертизы в 1914 году. Журнал М-ва юстиции. 1915. № 6. С. 323-345.

15. Государственный архив Российской Федерации. Ф. Д-во 8. Оп. 1908. Д. 14.

16. Крылов И. Ф. Розыск, дознание, следствие / И. Ф. Крылов, А. И. Бастрыкин. - Л.: Издательство Ленинград. ун-та, 1984. 217 с.

17. ЦДІАК України. Ф. 442. Оп. 855. Спр. 530.

18. Рильський М. Зібрання творів: у 20 т. / Максим Рильський. Київ: Наук. думка, 1983. T. 3. 439 c.

19. Резник Г. М. Дело Менделя Бейлиса: материалы Чрезвычайной следственной комиссии Временного правительства о судебном процессе 1913 г. по обвинению в ритуальном убийстве / Г. М. Резник. СПб.: Дмитрий Буланин, 1999. 393 с.

20. Чисников В. Н. Рудой Георгий Михайлович (1863 - после 1917) / В. Н. Чисников. Криміналістичні реєстраційно-довідкові й судово-експертні установи Міністерства внутрішніх справ та Міністерства юстиції Російської імперії (1889-1917 рр.): у 2-х кн. / Вербенський М. Г., Проценко Т. О., Чисніков В. М. та ін. Київ; Харків, 2013. Кн. 1.

21. Последние новости. 1918. 1 марта (16 февр.).

22. Чисніков В. М. Г.М.Рудий - майстер поліцейського розшуку / В. М. Чисніков. Іменем Закону. 2003. № 33, 34, 36, 37, 39-43.

23. Чисніков В. М. Батько вітчизняної дактилоскопії / В. М. Чисніков. Юрид. вісн. України. 2003. 13-19 груд.

24. Чисніков В. М. Г. М. Рудий - піонер української криміналістики / В. М. Чисніков. Юридична наука та освіта: історія, сучасність, перспективи: матеріали IX істор.-прав. конф. (Рівне, 6-8 черв. 2003 р.). Київ, 2004. С. 149-157. 
25. Чисніков В. М. Г.М.Рудий - піонер української криміналістики / В. М. Чисніков. Криміналіст. вісн. 2004. № 2. С. 134-1041.

26. Чисников В. Н. Г. М. Рудой - новатор полицейского сыска / В. Н. Чисников. Оперативник (сыщик). 2006. № 1 (6). С. 3-5; № 4 (9). С. 7-12.

27. Чисніков В. М. Новації Г. М. Рудого в карно-розшуковій справі / В. М. Чисніков. Наука і правоохорона. 2008. № 1. С. 132-138.

28. Чисніков В. М. Криміналістика України в XIX - поч. XX століття / В. М. Чисніков. Криміналістика: підручник / за заг. ред. П. Д. Біленчука. Київ: Атіка, 1998. С. 43-58.

29. Чисніков В. М. Рудий Георгій Михайлович / В. М. Чисніков. Міжнародна поліцейська енциклопедія: у 10 т. / відп. ред. Є. М. Моісеєв, В. Я. Тацій, Ю. С. Шемшученко. Київ, 2009. Т. V. Кримінально-процесуальна та криміналістична діяльність поліцейських організацій. С. 74.

30. Чисніков В. М. Рудий Георгій Михайлович / В. М. Чисніков. Міжнародна поліцейська енциклопедія:у8-мит. /відп. ред. КоваленкоВ. В., МоісеєвЄ. М., ТаційВ.Я., ШемшученкоЮ.С. Київ, 2010. T. VI. Оперативно-розшукова діяльність поліції (міліції). С. 899.

31. Чисников В. Н. Три портрета мастеров сыска / В. Н. Чисников. Антология сыска: от полиции к внешней разведке / отв. ред. Римаренко Ю. И., Чисников В. Н., Кушерец В. И. Киев, 2006. Т. 2. С. 249-286.

32. Чисніков В. М. Сискна поліція в Україні за часів Російської імперії (1880-1917рр.): істор.-прав. дослідж.: у 2-х кн. / В. М. Чисніков. Київ, 2011. Кн. І. Документи і матеріали. C. 307-353.

33. Чисніков В. М. Метр сискної справи. Криміналістичні пріоритети київського сищика Георгія Рудого / В. М. Чисніков. Юрид. вісн. України. 2018. 4-17 трав. 